\title{
Development of the Internationalization Process in Higher Education of Kazakhstan
}

\section{Bayan Maudarbekova}

PhD doctorate student, Zhetysu State university named after I.Zhansugurov, Taldykorgan, Kazakhstan;

Email: bayan.maudarbekova@gmail.com

Fatma Mizikaci

Associate professor, Ankara University,Ankara, Turkey

\section{Raifa Dyusembinova}

Doctor of pedagogical sciences, Zhetysu State university named after I.Zhansugurov, Taldykorgan, Kazakhstan

\author{
Doi:10.5901/mjss.2015.v6n5s1p248
}

\section{Abstract}

The article deals with the current process of internationalization of higher education and the state of higher education of the Republic of Kazakhstan after joining to the Bologna process. Incorporation of higher education of the Republic of Kazakhstan into the world educational area while preserving and developing the achievements and traditions of Kazakh higher school is one of the standards of state policy in education. The overall objective of education reform in Kazakhstan is the adaptation of the education system to the new socio-economic environment.

Keywords: higher education, internationalization, Bologna process, world educational area

\section{Introduction}

"The defining trend of modern education is, of course, the internationalization. As if we did not isolate our country, however, the general trends in the world of education and science prevail. We cannot stay away from these trends, and in the framework of the Shanghai Cooperation Organization (SCO) cooperation of these trends can be traced quite clearly. In particular, if we talk about the Kazakhstani education system, our system has undergone quite a radical change, and these changes are caused by our desire to follow the world trends in science and education", - said Murat Orunkhanov, vice minister of education and science of the Republic of Kazakhstan at the $2^{\text {nd }}$ Forum of Rectors of the Shanghai Cooperation Organization (Orunkhanov, 2013).

Therefore, the objective of the paper is to research the internationalization process in education in the Republic of Kazakhstan after joining the Bologna process.

Officially identified as the most considerable and wide-ranging reform of higher education in Europe since 1968 the Bologna process aimed at creating the European Higher Education Area (EHEA), in which academics and undergraduates will have greater mobility and their qualifications will be recognized. As it is written in the article of N.Pak, "our country takes the act, despite the matter of fact that the country is not eligible for membership of the EHEA, as it is not a signatory to the European Cultural Convention" (Pak, 2010). Nevertheless, Kazakhstan was praised for pioneering efforts to reform its higher education system in accordance with the guidelines of the Bologna process.

Consequently, the scale of the Bologna process to Kazakhstan's higher education system seeks to:

1) Find a harmonious balance between Bologna convergence and state originality;

2) Establish the internal balance between the stages of the Bologna Process. In many countries noticed the emergence of a new dialogue at the public level between the management and universities whose mission is to meet the best requests for reforming education systems.

\section{Literature Review}

Recently, the issue of internationalization of education are being researched by economists, political scientists, sociologists, but first of all, it interests teachers who are directly involved in the educational process of examining the 
problem of high school in the immediate vicinity. Scientific research conducted in the field of pedagogy, in our opinion, most clearly and systematically describe the specifics and the basic and main trends of internationalization in higher education of the Republic of Kazakhstan, reflect the characteristics of the internationalization of higher education, open forms and means of organizing the internationalization of the university.

Various aspects of the internationalization of education were considered by Russian and foreign scientists. Globalization of higher education was studied by Bauman Z. (Bauman, 2004), Scott P. (Scott, 2000), Knight J., F. Altbach (Knight \& Altbach, 2007) and others.

The signing of Magna Carta of universities which is the base of the Bologna Declaration is a serious step towards integration. Currently 30 universities of Kazakhstan signed Magna Carta of Universities which, despite its nongovernmental status became the foundation for the acceptance hereafter of many significant political decisions. Magna Carta aims universities to train the high-grade specialists which, undoubtedly, will find their place in life and will be successfully promoted. Simultaneously evolution of stipulations for students is an essential sector of the characteristic confidence system enhancing the character of institutions.

For that matter, it is impossible not to concentrate on the performance of higher education essential part of that is a permanent evaluation of its category. The notion of characteristic is inextricably linked with the idea of accreditation in the training sphere. In the scope of the overall internationalization of higher education international accreditation as a technique of evaluating the rate recently gets particularly significant characteristic of all higher educational institutions of the country, moreover, that the accreditation procedure is a prerequisite for the republic's joining into the Bologna process.

As it is said in the Message of the President of the Republic of Kazakhstan, "Education is admitted as one of the major precedencies of the long-time strategy "Kazakhstan - 2030". The pervasive purpose of education reform in Kazakhstan is to specialize the education system to the new socio-economic conditions. The leader of the nation Nursultan Nazarbayev also set the purpose to join Kazakhstan in the 50 most competitive regions in the world" (Nazarbayev, 2006).

However, for the full internationalization students should have accession to alternative educational proposals as the joint degree program, a program to obtain two degrees and notice to the learning of foreign languages.

"The Republic of Kazakhstan should be identified worldwide as a highly educated nation where people speak three languages, - accentuated the President. They are: Kazakh, Russian and English" (Nazarbayev, 2012). For Kazakhs the concept of languages triune is particularly significant because it was enunciated by the leader of the nation in response to the time challenge as a decision to lively demands of society which is dynamically joining into the global world. The joining of Kazakhstan into the global world presently depends on the realization and fulfillment of a general true: the universe is open to anybody who can get new experience by the excellence of the prevailing language. The fulfillment idea of polylinguism in education was started owing to the initiative of the leader of the nation because it will reinforce the ability of multilinguism in Kazakhstan.

\section{Discussion}

Theoretical and methodological basis of the paper were:

- the concept of a holistic world of pedagogical process (Vulfson, 1998) and world educational space (Tangyan, 1991);

- works on the methodology of modern comparative pedagogical research (Holmes, 1992; Khoi, 1986; Schriewer \& Holmes, 1992);

- $\quad$ the concept of modern education (Pinsky, 2001; Serikov, 1999);

Presently, it is the era of the historic progress of the worldwide system of higher education when state isolation of universities increasingly comes into conflict with consequences and prospects of the internationalization and globalization. This fundamental conflict appears in a variety of challenges: acknowledgement of academic degrees, specializations and assessments, evolution of Trans border forms of quality assessment, matters of international accreditation.

In the concept of scientific, technical and innovation policy in the education system of the Russian Federation up to 2015 the internationalization of higher education is considered as a process that takes place at state, sectorial and institutional levels where the objectives, purposes and techniques of academic services get international borders. Today, the internationalization of education is the object and subject of a deliberate course of the management to address national, state, societal and fiscal problems (The concept of scientific, technical and innovation policy in the education system of the Russian Federation up to 2015, 2011). 
Internationalization of education is the formation of a rational system of education what is applicable to many countries (Yatsenko, 1999). In contemporary literature there are various definitions of the concept of "the internationalization of education". In our opinion, the more successful is the definition of J. Knight: "Internationalization is the manner of fulfilment of the trans-border component of the prospect, instruction and administrative purposes of higher education". The specificity of this definition is in spite of the fact that the author indicates the inextricable link between all the goals of higher education in the course of internationalization and complex impact on the internationalization of the abovementioned functions (Knight, 2007).

The concept of internationalization in higher education includes two aspects: inner and outer internationalization or education abroad, cross-country education and trans-boundary education. Internationalization of education includes forms of reciprocal collaboration like individual mobility, the mobility of students or teaching staff for academic purposes; mobility of training programs and institutional mobility; preparation of new international standards for educational programs; embodiment into the international dimension of instructional programs and academic standards; institutional partnerships; the ascertainment of strategic educational alliances (Shimko, 2008).

The joint of our republic into the world educational and informational area is connected with the quest for new ways of personality growth of the modern specialist able to freely navigate in a multicultural world. The internationalization of higher education is not only the interchange of undergraduates and the signing of collaboration conventions, this act involves the initiation of international norms in all aspects of research-based and educational activities, both at the regional level and at the scholastic level (Standards and regulations of the Ministry of Education and Science of the Republic of Kazakhstan, 2015).

National course in education as a major priority aims to promote global educational area and practical evolution of technologies leading to scientific and academic centers. The strategic objectives facilitate to the internationalization aimed at character of training, the extension of the education market, the consolidation of Kazakhstan's state in the world community.

The internationalization process was a difficult and controversial. As long as there is no proper balance between its economic, cultural and academic purposes the necessity to strengthen the trans-border component of academic projects increases. The question of diplomas convertibility is significant; the forming of a common global educational market is in its early beginning. Still remain the questions of effective education of qualified staff for such a market. The influx of undergraduates from the expanding countries to universities raises the issue question of intercultural dialogue. There is growing need for the introductions of new communication technologies which unlike traditional international contacts do not have clearly defined limits and dramatically extend the abilities of collaboration.

\section{Conclusion}

After gaining independence Kazakhstan pays great attention to education, in addition to the involvement of the regional example of training in the trans-border educational area. Therefore, in the statement of the Leader of Kazakhstan evolution of the state socio-economic modernization was defined as the major direction which includes 10 different directions.

\section{References}

Altbach P. \& Knight J. (2007).The internationalization of higher education: motivations and realities. Journal of studies in international education. Fall/winter Volume 11.

Bauman Z. (2004). Globalization: Implications for the individual and society. Moscow, p. 112.

Holmes B. (1992).Causality, Determinism and Comparative Education as a Social Science. Theories and methods in comparative education.- Frankfurt am Main\& New York: Peter Land, p. 115.

Khoi L.T. (1986). Toward a General Theory of Education. New Approaches to Comparative Education. Chicago: The University of Chicago Press. -p. 232.

Knight J. (2007). Internationalization of education brings not only benefit. Economics of Education. Volume 5, p. 79.

Message of the President of the Republic of Kazakhstan N.A. Nazarbayev to the people of Kazakhstan. (2006, March 1). Kazakhstanskaya pravda.

Nazarbayev N.A. Social modernization of Kazakhstan: Twenty Steps to a society of universal labor.(2012, July 20) Kazakhstanskaya pravda.

Pak N. (2010). Integration of the Republic of Kazakhstan into Global Educational Scenario: from Reforms in Education to Quality Assurance Enhancement and World Ranking Participation. Global management journal, Volume 3, No.2. http://globalmj.eul 2010/12/09/integration-of-the-republic-of-kazakhstan-into-global-educational-scenario-from-reforms-in-education-to-quality- 
assurance-enhancement-and-world-ranking-participation/

Pinsky A.A. (2001). The modernization strategy of general education. Moscow: World of Books.

Schriewer J., Holmes B. (1992). Theories and methods in comparative education. -Frankfurt am Main \& New York: Peter Lang.

Scott P. (2000). Globalization and the University. Alma mater. Volume 4, p.3

Serikov V.V. (1999). Education and personality. The theory and practice of designing educational systems. - Moscow:Logos. - $272 \mathrm{p}$.

Shimko P.D. (2008). Management of the processes of globalization of higher education at university and regional levels. Economy. Volume 3, p. 286.

Standards and regulations of the Ministry of Education and Science of the Republic of Kazakhstan. http://orleu-edu.kz/Standars_eng. May 25, 2015

Tangyan S. (1991). International Literacy Year. Moscow: Contemporary Higher Education. -Volume 1. p.24.

The concept of scientific, technical and innovation policy in the education system of the Russian Federation up to 2015 (2011). Decree of the Government of Russian Federation on December 8, 2011, N 2227. Moscow.

Wolfson B.L. (1998). Western European space of the XXI century: Pedagogy predictive models. Moscow: Pedagogika. p.103.

Yatsenko N.E. (1999). The explanatory dictionary of social science terms. Moscow: Lan. p. 236. 